Endocrinol. Japon. 1985, 32 (2), 233 240

\title{
In Vivo and in Vitro Effects of Angiotensin II on the Release of $\beta$-Endorphin-Like Immunoreactivity
}

\author{
'Mitsuhiro MATSUmUra, Shuji INOUE, Akira Yamanoi, \\ Kazumasa CHIKAMORI and '2 Shiro SAITO \\ ${ }^{1}$ Second Department of Internal Medicine, School of Medicine, \\ University of Tokushima, Tokushima 770 \\ ${ }^{2}$ First Department of Internal Medicine, School of Medicine, \\ University of Tokushima 770
}

\begin{abstract}
The effect of angiotensin II (A II) on the release of $\beta$-endorphin-like immunoreactivity ( $\beta$-END-LI) in rats was studied in vivo and in vitro. Intravenous injection of $1 \mu \mathrm{g} / 100 \mathrm{~g}$ body weight of A II resulted in significant increase in the plasma $\beta$-END-LI level after 10 and 20 min. Intraventricular injection of $1 \mathrm{ng} / 100 \mathrm{~g}$ body weight of A II also resulted in significant increase in the plasma $\beta$-END-LI level after $10 \mathrm{~min}$. A II at concentrations of $10^{-12} \mathrm{M}$ $10^{-10} \mathrm{M}$ caused dose-dependent stimulation of $\beta$-END-LI release from dispersed cells of rat anterior pituitary. On gel chromatography, the $\beta$-END-LI released by incubation of the cells with $10^{-10} \mathrm{M}$ A II separated into two components which eluted in the same positions as human $\beta$-lipotropin and human $\beta$-endorphin, respectively. The ratio of $\beta$-LPH to $\beta$-END in these fractions was $5: 1$ on a molar basis. A II did not stimulate $\beta$-END-LI release in $\mathrm{Ca}^{++}$-free-medium. [Sar ${ }^{1}, \mathrm{Ala}^{8}$ ]-A II at concentrations of $10^{-9} \mathrm{M}-10^{-7} \mathrm{M}$ did not stimulate $\beta$-ENDLI release from the cells. Addition of $\left[\mathrm{Sar}^{1}, \mathrm{Ala}^{8}\right]$-A II to the incubation medium inhibited A II-induced $\beta$-END-LI release from the cells.

These results indicate that A II acts, at least in part, directly on anterior pituitary cells to stimulate $\beta$-END-LI release and that calcium ion is involved in the mechanism of this effect.
\end{abstract}

$\beta$-Endorphin ( $\beta$-END), an endogenous opioid peptide is known to be localized in the pituitary gland, brain, gut and pancreas (Rossier et al., 1977; Orwoll and Kendall, 1980 ; Bruni et al., 1979). Release of $\beta$ END from the pituitary gland is thought to be controlled by the same mechanism as that of adrenocorticotropic hormone (ACTH)

Received September 3, 1984 and $\beta$-lipotropin and, like these components, $\beta$-END is thought to act as a stress hormone. Angiotensin II (A II) has a variety of actions in the central nervous system: it controls fluid intake (Estein et al., 1970), electrolyte balance (Freeman and Davis, 1979 ; Ploth and Naval, 1979), blood pressure (Sirett et al., 1979), and the releases of arginine vasopressin (ADH) (Share, 1979) and ACTH (Sobel and Vagnucci, 1982). In 
the brain, it is present at high concentration in the anterior hypothalamus and the median eminence, suggesting that it acts as a neurotransmitter or neuromodulator. Recently, it has reported that binding sites for A II exist in the anterior pituitary cells (Mukherjee et al., 1982; Capponi et al., 1982). In fact, Sobel and Vagnucci (1982) and Schramme and Denef (1983) reported that A II stimulates the release of ACTH and prolactin from rat pituitary. But its action on $\beta$-END secretion from the anterior pituitary is still unknown.

In the present study, we examined the effect of A II on the release of $\beta$-endorphinlike immunoreactivity $(\beta$-END-LI) in vivo and its release from dispersed cells of rat anterior pituitary. The mechanism of A IIinduced $\beta$-END-LI release was studied in relation to calcium.

\section{Materials and Methods}

Male Wister strain rats weighing 200-250 g were housed under controlled conditions of light (0700-1900 h) and temperature with free access to laboratory rat chow and water. They were divided into 5 groups of 5 rats each and in jected intraperitoneally with pentobarbital $(5 \mathrm{mg} / 100 \mathrm{~g}$ BW, Abbott Laboratories, USA). Three groups were injected with physiological saline $(0.1 \mathrm{ml} /$ $100 \mathrm{~g} \mathrm{BW}$ intravenously or $2 \mu \mathrm{l} / 100 \mathrm{~g} \mathrm{BW}$ intraventricularly), two groups were given A II (Protein Foundation Minoo, Japan; $5 \mathrm{mg} / 0.1 \mathrm{ml}$ physiological saline $/ 100 \mathrm{~g} \mathrm{BW}$ ) via the tail vein and two groups were given A II $(1 \mathrm{ng} / 2 \mu \mathrm{l}$ physiological saline/100 $\mathrm{g} \mathrm{BW}$ ) intraventricularly using a $10-\mu \mathrm{l}$ Hamilton microsyringe. The rats were killed by decapitation 0,10 , and $20 \mathrm{~min}$ after injection of physiological saline and 10 and 20 min after injection of A II and blood samples for determination of $\beta$-END-LI were put into test tubes containing EDTA (1 mg per $1 \mathrm{ml}$ blood) and Trasylol (500 KIU per $1 \mathrm{ml}$ blood). The time of sacrifice was adjusted to $45 \mathrm{~min}$ after injection of pentobarbital. Blood plasma was separated by centrifugation at $2,000 \times \mathrm{g}$ for 15 min at $4^{\circ} \mathrm{C}$ and kept $-20^{\circ} \mathrm{C}$ until examined.
Preparation of dispersed cells from the anterior pituitary gland

Cells of the anterior pituitary were dispersed by a modification of the method of Yeo et al. (1979) as reported previously (Matsumura et al., 1982 b). In brief, the anterior pituitaries of 15 adult male Wistar rats weighing $200-250 \mathrm{~g}$ were minced with fine scissors and transferred to a spinner bottle (Bellco Glass Inc., Vineland, NJ, USA) with crystalline trypsin $(2.5 \mathrm{mg} / \mathrm{ml}$, Worthington Biochemical Corp.) and deoxyribonuclease (DNase, $40 \mu \mathrm{g} / \mathrm{ml}$, Sigma Chemical Co.). The tissues were stirred gently at $37^{\circ} \mathrm{C}$ for $20 \mathrm{~min}$ in an atmosphere of $95 \% \quad \mathrm{O}_{2}$ and $5 \% \quad \mathrm{CO}_{2}$. The mixture was then pipetted back and forth about 20 times and transferred to a test tube, and the cloudy supernatant containing the dispersed cells was carefully separated. This dispersion procedure was repeated a total of four times. The four supernatants obtained were centrifuged at $4,000 \times \mathrm{g}$ for $45 \mathrm{sec}$ at room temperature and the supernatant was discarded. The precipitated cells were resuspended in $2 \mathrm{ml}$ of Earle's balanced salts solution (EBSS) containing lima bean trypsin inhibitor $(0.5 \mathrm{mg} / \mathrm{ml}$, Worthington Biochemical Corp.), centrifuged and resuspended in EBSS containing bovine serum albumin $(2.5 \mathrm{mg} /$ ml) (EBSS-BSA). The latter procedure was repeated three times more. Before the final centrifugation, the number of dispersed cells was determined. The resulting suspension of cells was preincubated at $37^{\circ} \mathrm{C}$ for $2 \mathrm{~h}$ and used for incubation as described below.

\section{Incubation of dispersed cells of rat anterior pituitary}

A suspension of $1 \times 10^{5}$ dispersed cells in $1 \mathrm{ml}$ of incubation medium was first incubated in a shaking water bath at $37^{\circ} \mathrm{C}$ for $60 \mathrm{~min}$ in an atmosphere of $95 \% \mathrm{O}_{2}$ and $5 \% \quad \mathrm{CO}_{2}$. The medium was then changed to medium containing a test material in EBSS-BSA. After incubation for $60 \mathrm{~min}$, the cells were precipitated by centrifugation, and the medium was stored at $-20^{\circ} \mathrm{C}$ for $\beta$-END assay.

\section{Radioimmunoassay of $\beta$-endorphin}

Anti-human $\beta$-END ( $\beta_{h}$-END) serum was prepared by the method of Guillemin et al. (1977) and proved to be highly specific for $\beta_{h}$ END as reported previously (Matsumura et al., 1982 a). It showed only $4.5 \%$ cross-reactivity with human $\beta$-lipotropin $\left(\beta_{\mathrm{h}}-\mathrm{LPH}\right)$ on a molar 
basis and did not cross-react with other proopiocortin-related peptides tested, ircluding human enkephalins, human endorphins $(\alpha, \gamma$ and $\delta)$, human $\gamma$-LPH and human ${ }^{1-39} \mathrm{ACTH}$. Syethetic $\beta_{\mathrm{l}}$-END was radioiodinated with ${ }^{125} \mathrm{I}$ by the chloramine $\mathrm{T}$ method (Hunter and Greenwood, 1962), and $\left[{ }^{125} \mathrm{I}\right] \beta_{\mathrm{h}}$-END was separated on a column $(1 \times 18 \mathrm{~cm})$ of Sephadex G-25 (medium). The procedure for $\beta_{\mathrm{l}}$-END radioimmunoassay was reported in detail previously (Matsumura et al., 1982 a). [ [25I] $\beta_{\mathrm{h}}$-END bound to the antibody was released by unlabeled hormone in a dose-related manner in the range of 1.1-73.1 fmole/tube. Plasma $\beta$-END-LI was measured by radioimmunoassay after its extraction with acidacetone and petroleum ether (Matsumura et al., $1982 \mathrm{c}$ ).

Gel-filtration chromatography of $\beta_{\mathrm{h}}$-END-LI released into the incubation medium

After incubation for $60 \mathrm{~min}, 1 \mathrm{ml}$ of medium was lyophilized and dissolved in $0.2 \mathrm{~N} \mathrm{HCl}$. The solution was heated in a boiling water bath for $10 \mathrm{~min}$ and applied to a colum $(0.9 \times 45 \mathrm{~cm})$ of Sephadex G-50 (fine) and materials were eluted with $0.1 \mathrm{~N}$ acetic acid containing $0.1 \% \mathrm{BSA}$ at a flow rate of $15 \mathrm{ml} / \mathrm{h}$ at room temperature. Fractions of $1 \mathrm{ml}$ of eluate were collected, lyophilized, dissolved in the assay buffer and subjected to radioimmunoassay. The column was calibrated with blue dextran, synthetic $\beta_{\mathrm{h}^{-}}$ $\mathrm{LPH}$, synthetic $\beta_{\mathrm{h}}$-END and $\mathrm{Na}{ }^{125} \mathrm{I}$.

\section{Statistics}

The statistical significance of differences was analyzed by Student's $t$-test.

\section{Results}

Effect of $A$ II on $\beta$-END-LI release in vivo As shown in Figure 1, there was no significant change in the plasma $\beta$-END-LI level 10 and $20 \mathrm{~min}$ after intravenous administration of physiological saline $(0.1$ $\mathrm{ml} / 100 \mathrm{~g}$ body weight). However, after intravenous injection of $1 \mu \mathrm{g} / 100 \mathrm{~g}$ body weight of A II the plasma $\beta$-END-LI level rose significantly from a basal level of $13.1 \pm 1.7$ to $39.3 \pm 2.4 \mathrm{pmol} / 1$ (mean $\pm S E M$, $\mathrm{p}<0.001)$ at $10 \mathrm{~min}$ and $31,6 \pm 1.6 \mathrm{pmol} / \mathrm{l}$ $(\mathrm{p}<0.001)$ at $20 \mathrm{~min}$.
Effect of intraventricular injection of $A$ II on $\beta-E N D$ - $L I$ release in vivo

As shown in Figure 2, there was no signiflcant change in the plasma $\beta$-END-LI level 10 or $20 \mathrm{~min}$ after intraventricular injection of physiological saline $(2 \mu \mathrm{l} / 100 \mathrm{~g}$

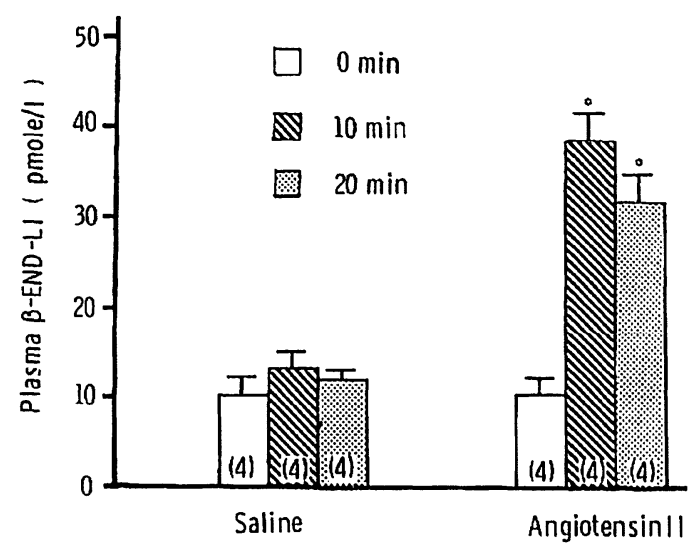

Fig. 1. Plasma $\beta$-END-LI levels after iv injection of physiological saline $(0.1 \mathrm{ml} \mathrm{BW})$ or $A I I(I$ $\mu g / 100 \mathrm{~g} \mathrm{BW})$

Values are means $\pm S E M$. Figures in parentheses indicate numbers of rats.

* $\mathrm{p}<0.001$ vs contro!.

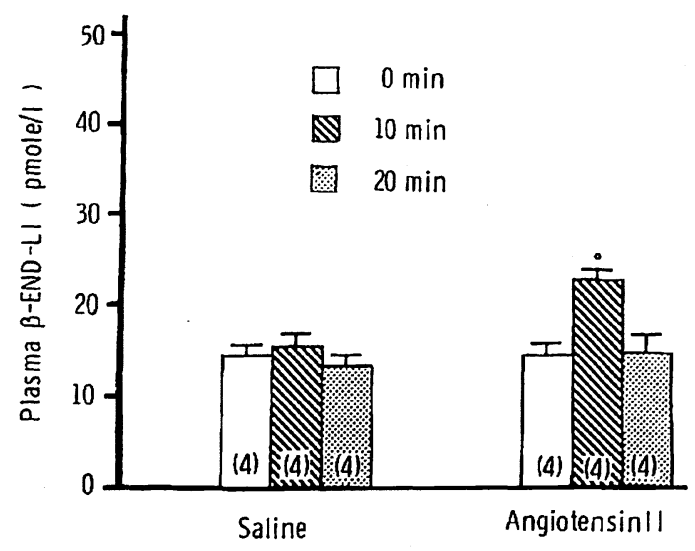

Fig. 2. Plasma $\beta-E N D-L I$ level after intraventricular injection of physiological saline $(1 \mu l)$ $100 \mathrm{~g} \mathrm{BW}$ ) or $A$ II $(\mathrm{I} \mathrm{ng} / 100 \mathrm{~g} \mathrm{BW})$

Values are means $\pm S E M$. Figures in parentheses indicate numbers of rats.

$* \mathrm{p}<0.005$ vs control. 
$\mathrm{BW}$ ). However, the plasma $\beta$-END-LI level rose significantly after intraventricular injection of $1 \mathrm{ng} / 100 \mathrm{~g} \mathrm{BW}$ of A II from a basal level of $15.3 \pm 0.9$ to $18.6 \pm 0.9 \mathrm{pmol} / 1$ (mean $\pm S F M, p<0.005$ ) at $10 \mathrm{~min}$, although it was not significantly increased at $20 \mathrm{~min}$.

Time course of $\beta$-END-LI release from dispersed cells on incubation with $A I I$

$\beta$-END-LI release from dispersed cells of rat anterior pituitary into the medium was significantly increased from $60 \mathrm{~min}$ after addition of $\mathrm{A}$ II at a concentration of $10^{-10}$ $M$ to at least the end of the observation period at $180 \mathrm{~min}$ (Fig. 3).

Effect of $A I I$ on the release of $\beta-E N D-L I$ from dispersed cells

The addition of $A$ II at concentrations of $10^{-12}-10^{-10} \mathrm{M}$ to the incubation medium caused a dose-dependent increase in the release of $\beta$-END-LI from dispersed cells of rat anterior pituitary. However, the addition of A II at concentrations of $10^{-10}-10^{-7} \mathrm{M}$ to the incubation medium caused a dosedependent decrease in the release of $\beta$-ENDLI from dispersed cells of rat anterior pituitary (Table 1).

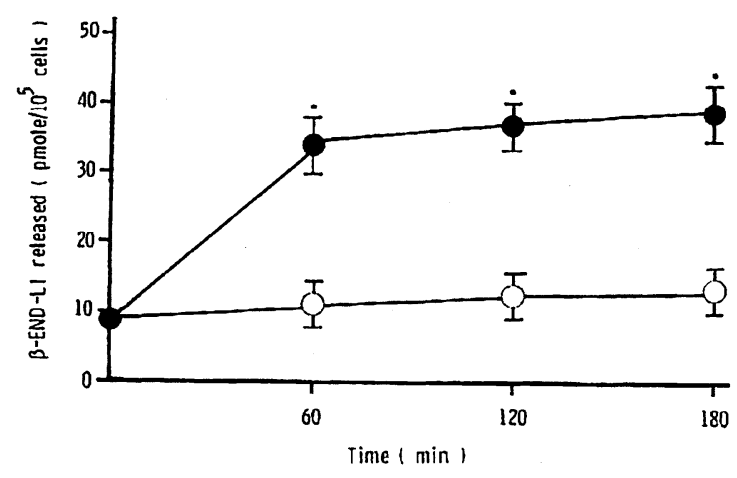

Fig. 3. Time course of release of $\beta$-END-LI from dispersed cells of rat anterior pituitary in the absence $(\mathrm{O})$ and presence $(O)$ of $10^{-10} \mathrm{M} \mathrm{AII}$ Points and bars are means \pm SEM for 4 experiments.

* $\mathrm{p}<0.01$ vs the corresponding control value.
Size heterogeneity of $\beta-E N D-L I$ released from dispersed cells

After the incubation of dispersed cells with $10^{-10} \mathrm{M}$ A II, the medium was chromatographed on a column $(0.9 \times 45 \mathrm{~cm})$ of Sephadex G-50. As shown in Figure 4, two components of $\beta$-END-LI were detected in the medium: one was eluted in the same position as $\beta_{\mathrm{h}}-\mathrm{LPH}$, and the other in the same position as $\beta_{\mathrm{h}}$-END. The ratio

Table 1. Dose-response to A II of $\beta$-ENDLI release from dispersed cells of rat anterior putuitary

\begin{tabular}{cc}
\hline $\begin{array}{c}\text { A II } \\
\text { Concentration (M) }\end{array}$ & $\begin{array}{c}\beta \text {-END-LI released } \\
\text { (fmole/60 min } / 10^{5} \text { cells) }\end{array}$ \\
\hline 0 & $194.0 \pm 8.0$ \\
$10^{-12}$ & $296.0 \pm 10.6^{* * *}$ \\
$10^{-11}$ & $375.1 \pm 12.9^{* *}$ \\
$10^{-10}$ & $432.9 \pm 18.6^{* *}$ \\
$10^{-9}$ & $342.9 \pm 20.9^{* *}$ \\
$10^{-8}$ & $277.1 \pm 5.1^{* *}$ \\
$10^{-7}$ & $256.6 \pm 25.1^{*}$ \\
\hline
\end{tabular}

Values are means \pm SEM for five experiments. $* \mathrm{p}<0.01$ vs control.

** $\mathrm{p}<0.001$ vs control.

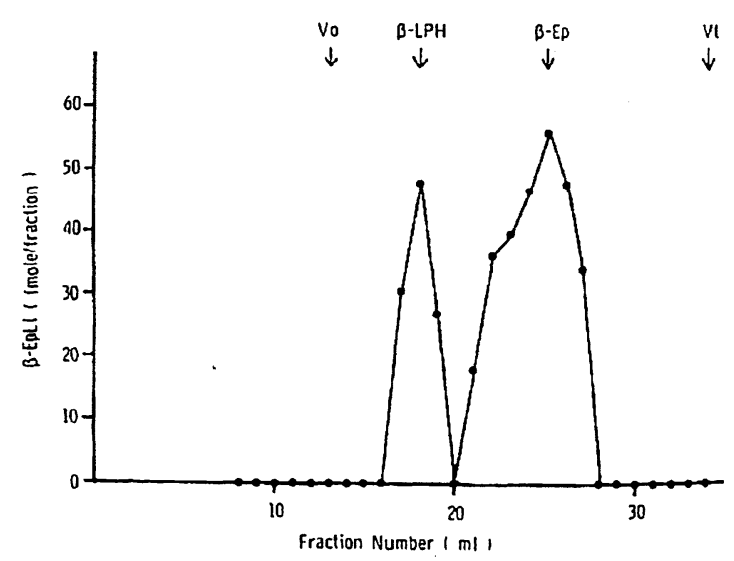

Fig. 4. Gel-filtration chromatography on Sephadex $6-50$ of $\beta-E N D-L I$ released from dispersed cells of rat anterior pituitary in the presence of $10^{-10} \mathrm{M} A \mathrm{II}$

The colum $(0.9 \times 45 \mathrm{~cm})$ was calibrated with synthetic $\beta_{\mathrm{h}}-\mathrm{LPH}$ and synthetic $\beta_{\mathrm{h}}$-END. 
of $\beta$-LPH to $\beta$-END in these fractions was 5:1 on a molar basis.

Effect of calcium ion on $A$ II induced $\beta$ END-LI release from dispersed cells

Enhancement of $\beta$-END-LI release from dispersed cells by incubation for $60 \mathrm{~min}$ with $10^{-10} \mathrm{M}$ A II was completely prevented by omission of $\mathrm{Ca}^{++}$from the incubation medium. Addition of $\mathrm{Ca}^{++}$to the medium at concentrations of $1.25-2.5 \mathrm{mM}$ caused a linear increase in the release of $\beta$-END-LI induced by A II. At concentrations of above $2.5 \mathrm{mM} \mathrm{Ca}{ }^{++}$, the release reached a plateau (Fig. 5).

Effect of $\mathrm{Co}^{++}$on $A$ II-induced $\beta$-END-LI release from dispersed cells

The addition of $2 \mathrm{mM} \mathrm{CoCl} 2$ alone to

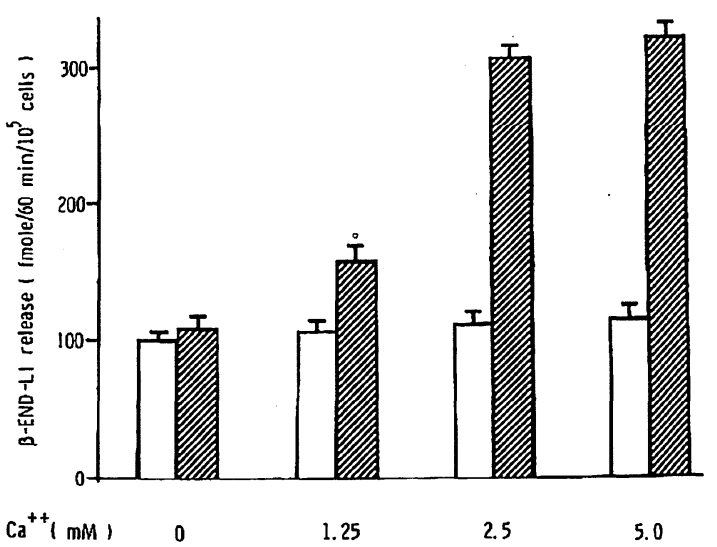

Fig. 5. Effect of calcium ion on $\beta-E N D-L I$ release from dispersed cells of rat anterior pituitary induced by $10^{-10} \mathrm{M} A \mathrm{II}$

The cells were suspended in EBSS-BSA $\left(\mathrm{Ca}^{++}\right.$ free, no EGTA) and then used for experiments with or without addition of calcium ion and A II. The cells were incubated at $37^{\circ} \mathrm{C}$ for $60 \mathrm{~min}$ in medium containing $0 \mathrm{mM}, 1.25 \mathrm{mM}$, $2.5 \mathrm{mM}, 5 \mathrm{mM} \mathrm{Ca}{ }^{++}$without A II $\square$ ): $0 \mathrm{mM}, 1.25 \mathrm{mM}, 2.5 \mathrm{mM}, 5 \mathrm{mM} \mathrm{Ca}{ }^{++}$with $10^{-10} \mathrm{M}$ A II (UIIT). Values are means $\pm S E M$ for 4 experiments.

$*<0.05$ vs control.

$* * \mathrm{p}<0.001$ vs control. the incubation medium had no effect on $\beta$ END-LI release from dispersed cells during 60 min incubation period, but completely inhibited A II-induced $\beta$-END-LI release (Table 2).

Table 2. Effect of $\mathrm{CoCl}_{2}$ on $\mathrm{A}$ II-induced $\beta$-END-LI release from dispersed cells of rat anterior pituitary

\begin{tabular}{lc}
\hline \multicolumn{1}{c}{ Addition } & $\begin{array}{c}\beta \text {-END-LI released } \\
\text { (fmole/60 min/ } 10^{5} \text { cells) }\end{array}$ \\
\hline None & $225.7 \pm 5.7$ \\
$\mathrm{CoCl}_{2}(2 \mathrm{mM})$ & $203.1 \pm 6.9$ \\
A II $\left(10^{-10} \mathrm{M}\right)$ & $451.4 \pm 5.7^{*}$ \\
A II $\left(10^{-10} \mathrm{M}\right)$ & \\
plus $\mathrm{CoCl}_{2}(2 \mathrm{mM})$ & $202.6 \pm 5.1 \dagger$ \\
\hline
\end{tabular}

Values are means $\pm S E M$ for five experiments.

$* \mathrm{p}<0.001$ is control.

$\dagger \mathrm{p}<0.001$ is value with A II.

Table 3. Dose response to $\left[\mathrm{Sar}^{1}, \mathrm{Ala}^{8}\right]-\mathrm{A}$ II of $\beta$-END-LI release from dispersed cells of rat anterior pituitary

\begin{tabular}{lc}
\hline \multicolumn{1}{c}{ Addition } & $\begin{array}{c}\beta \text {-END-LI released } \\
\text { (fmole/ } / 180 \mathrm{~min} / 10^{5} \text { cells) }\end{array}$ \\
\hline None & $244.6 \pm 5.7$ \\
{$\left[\mathrm{Sar}^{1}\right.$, Ala $\left.^{8}\right]$-A II } & $272.0 \pm 5.4$ \\
$10^{-9}$ & $267.7 \pm 5.4$ \\
$10^{-8}$ & $259.4 \pm 4.9$ \\
$10^{-7}$ & \\
\hline
\end{tabular}

Values are means \pm SEM for five experiments.

Table 4. Effect of $\left[\mathrm{Sar}^{1}, \mathrm{Ala}^{8}\right]-\mathrm{A}$ II on A II-induced $\beta$-END-LI release from dispersed cells of rat anterior pituitary

\begin{tabular}{lc}
\hline \hline \multicolumn{1}{c}{ Addition } & $\begin{array}{c}\beta \text {-END-LI released } \\
\left.\text { (fmole/180 min } / 10^{5} \text { cells }\right)\end{array}$ \\
\hline None & $246.6 \pm 9.4$ \\
[Sar $\left.{ }^{1}, \mathrm{Ala}^{8}\right]-\mathrm{A}$ II $\left(10^{-7} \mathrm{M}\right)$ & $259.4 \pm 8.6$ \\
A II $\left(10^{-10} \mathrm{M}\right)$ & $410.9 \pm 6.3^{*}$ \\
A II $\left(10^{-10} \mathrm{M}\right)$ & \\
plus [Sar ${ }^{1}, \mathrm{Ala}^{8}$ ]-A II $\left(10^{-7} \mathrm{M}\right)$ & $266.0 \pm 6.3 \dagger$ \\
\hline
\end{tabular}

Values are means \pm SEM for four experiments.

* $\mathrm{p}<0.001$ vs control.

$\dagger \mathrm{p}<0.001$ vs value with A II. 
Effect of $\left[S a r^{-1}, A l a^{8}\right]-A$ II on $A$ II-induced release of $\beta-E N D-L I$ from dispersed cells

The addition of $\left[\mathrm{Sar}^{1}, \mathrm{Ala}^{\mathrm{s}}\right]-\mathrm{A}$ II at concentrations $10^{-9} \mathrm{M}$ to $10^{-7} \mathrm{M}$ to the incubation medium did not stimulate the release of $\beta$-END-LI from dispersed cells of rat anterior pituitary, as shown in Table 3. However, addition of $10^{-7} \mathrm{M}$ [Sar $\left.{ }^{1}, \mathrm{Ala}^{8}\right]-\mathrm{A}$ II to the incubation medium inhibited $A$ II-induced $\beta$-END-LI release, as shown in Table 4.

\section{Discussion}

A II has a wide variety of biological effects on the central nervous system (CNS), adrenal gland, liver, kidney, vascular smooth muscle, etc. (Peach, 1977). In the pituitary gland, it stimulates the releases of PRL, ACTH and ADH and inhibits those of GH and $L H$, probably due to its central action and/or direct action on the pituitary (Sobel and Vagnucci, 1982; Fitzsimons, 1972; Schrame and Denef, 1983; Steel et al., 1981).

The present work showed that intravenous and intraventricular administration of A II stimulated $\beta$-END and $\beta$-LPH release in rats. The source of the $\beta$-ENDLI released into the circulation was not clear, because $\beta$-END-LI is present in various tissues besides the pituitary (Orwoll and Kendall, 1980: Bruni et al., 1979; Nakai et al., 1978). In addition, it was not clear whether the in vivo effect of A II on $\beta$-END-LI release is physiological. Therefore, we performed in vitro studies and found that $A$ II at concentrations of $10^{-12} \mathrm{M}$ to $10^{-10} \mathrm{M}$ induced dose-dependent $\beta$-END-LI release from dispersed cells of rat anterior pituitary, although doses higher than $10^{-10} \mathrm{M}$ A II showed less stimulatory effect on $\beta$ END-LI release, which suggests that large doses of A II may have a toxic effect on the hormone release, but this remains to be studied. These findings indicate that A II can act directly on the pituitary.

The concentration of A II in the hypophysial portal vein is unknown. A II may have a physiological role in pituitary hormone release when its concentration in the hypophysial portal blood exceeds $10^{-12}$ M.

Although these in vivo and in vitro experiments show that A II may act directly on the pituitary gland and induce $\beta$-ENDLI release, we cannot eliminate the possibility that CNS may play a role in promoting $\beta$-END-LI release.

$\beta$-END, an endogenous opioid, has the same amino acid sequence as residues $61-91$ of $\beta-\mathrm{LPH}$, derived from the same precursor as ACTH. These three peptides are concomitantly released from the pituitary by stress, insulin hypoglycemia, and administrations of vasopressin and corticotropin releasing factor (CRF) (Wardlaw and Frantz, 1979 ; Przewlocki et al., 1979 ; Rivier et al., 1982). In vitro experiments have also shown that CRF, vasopressin and high extracellular $\mathrm{K}^{+}$concentration augment the release of these peptides (Vale et al., 1978 ; Przewlocki et al., 1979; Matsumura et al., 1982 b)

We found that $\beta$-END-LI release from dispersed cells in vitro was inhibited in $\mathrm{Ca}^{++}$-free medium, but that ouabain, which promotes calcium uptake by tissues through its interaction with membrane-bound $\mathrm{Na}^{+}$$\mathrm{K}^{+}$-ATPase (Vizi, 1978), stimulates $\beta$-ENDLI release (Matsumura et al., 1982 b). On the other hand, it has been demonstrated that elevation of the extracellular $\mathrm{K}^{+}$concentration stimulates the releases of ACTH (Kraicer et al., 1969), GH (MacLeod and Fontham, 1970), LH (Wakabayashi et al., 1969), TSH (Schwartz et al., 1972) and $\beta$ END-LI (Matsumura et al., 1982 b) from pituitary cells. High $\mathrm{K}^{+}$is thought to act by depolarizing the plasma membrane, resulting in an increase in $\mathrm{Ca}^{++}$influx, which would then induce hormone release.

The addition of cobalt ion, a competitive antagonist of calcium in transmembrane 
transport (Weakly, 1973), to the incubation medium inhibited A II-induced $\beta$-END-LI release. Since cobalt ion is known to prevent calcium influx into the cell, this finding suggests that A II stimulates $\beta$-ENDLI release from the pituitary cells at least in part by a $\mathrm{Ca}^{++}$-dependent mechanism.

The addition of $\left[\mathrm{Sar}^{1}, \mathrm{Ala}^{8}\right]-\mathrm{A}$ II, a competitive antagonist of A II for the receptor, to the incubation medium inhibited A II-induced $\beta$-END-LI release. Capponi et al. (1982) and Saltman et al. (1975) reported that $\left[\mathrm{Sar}^{1}, \mathrm{Ala}^{8}\right]-\mathrm{A}$ II, which is able to block the A II-induced ACTH release completely, was as effective as A II in displacing the labeled tracer, a result which is in agreement with the affinity of other target tissues for this analogue. This finding suggests that the stimulatory action of A II on $\beta$-END-LI release by dispersed rat pituitary cells may be mediated by specific receptors for the octapeptide.

The present work showed that A II stimulated $\beta$-LPH and $\beta$-END release in rats. In vitro studies using dispersed cells from the anterior pituitary also indicated that A II could act directly on the pituitary to stimulate $\beta$-LPH and $\beta$-END release, and that $\mathrm{Ca}^{++}$played an important role in their actions. The effect of A II on $\beta$-END-LI release from extrapituitary tissues and the significance of A II-induced $\beta$-END-LI release further studies.

\section{Acknowledgements}

This work was supported by a grant (No. 59770825) from the Ministry of Education, Science and Culture of Japan.

\section{References}

Bruni, J. E., W. B. Watkins, S. S. C. Yen (1979). $\beta$-Endorphin in the human pancreas. J. Clin. Endocrinol. Metab. 49, 649-651.

Capponi, A. M., C. A. Favrod-Coune, R. C.
Gaillard, A. F. Muller (19S2). Binding and activation properties of angiotensin II in dispersed rat anterior pituitary cells. Endocrinology' 110, 1043-1045.

Epstein, A., J. T. Fitzsimons, B. Rolls (1970). Drinking induced by injection of angiotensin into the brain of rats. J. Physiol. 210, 457474.

Fitzsimons, J. T. (1972). Thirst. Physiol. Rev. $52,468-561$

Freeman, R. H., J. D. Davis (1979). Physiological actions of angiotensin 11 on the kidney. Fed. Proc. 38, 2280-2285.

Guillemin, R., N. Ling, T. Vargo (1977). Radioimmunoassays for $\alpha$-endorphin and $\beta$-endorphin. Biochem. Biophys. Res. Commmu. 77, 361-366.

Hunter, W. H., F. A. Greenwood (1962). Preparation of iodine-131 labelled human growth hormone of high specific activily. Nature 194, 495-496.

Kraicer, J., J. V. Milligan, J. L. Gosbee, R. G. Conrad, C. M. Branson (1969). Potassium, corticosterone, and adrenocorticotropic hormone release in vitro. Science 164, 426.

MacLeod, R. M., E. H. Fontham (1970). Influence of ionic environment on the in vitro synthesis and release of pituitary hormone. Endocrinology 86, 863-869.

Matsumura, M., S. Saito, M. Fujino (1982 a). Effects of solution of low $\mathrm{pH}$ and taurocholate on release of $\beta$-endorphin-like immunoreactivity from human duodenal mucosa in vitro. Regul. Peptides 3, 173-181.

Matsumura, M., A. Yamanoi, S. Yamamoto, S. Saito (1982 b). In vivo and in vitro effects of substance $P$ on the release of $\beta$-endorphin-like immunoreactivity. Neuroendocrinology 35, 163 -168 .

Matsumura, M., N. Fukuda, S. Saito, H. Mori $(1982$ c). Effect of a test meal, duodenal acidification, and tetragastrin on the plasma concentrations of $\beta$-endorphin-like immunoreactivity in man. Regul. Peptides 4, 173-181.

Mukherjce, A., P. Kulkarni, S. M. McCann, A. Negro-Villar (1982). Evidence for the presence and characterization of angiotensin II receptors in rat anterior pituitary membranes. Endocrinology 110, 665-667.

Nakai, Y., K. Nakao, S. Oki, H. Imura (1978). Presence of immunoreactive $\beta$-endorphin in human placenta. Life Sci. 23, 2013-2018.

Orwoll, E., J. W. Kendall (1980). $\beta$-Endorphin and adreno-corticotropin in extrapituitary sites : 
gastrointestinal tract. Endocrinology 107, 438442.

Peach, M. J. (1977). Renin-angiotensin system : biochemistry and mechanism of action. Physiol. Rev. 57, 313-370.

Ploth, D. W., L. H. Naval (1979). Intrarenal effects of the renin-angiotensin system. Fed. Proc. 38, 2280-2285.

Przewlocki, R., V. Höllt, K. H. Voigt, A. Herz (1979). Modulation of in vitro release of $\beta$ endorphin from the separate lobes of the rat pituitary. Life Sci. 24, 1601-1608.

Rivier, C., M. Brownstein, J. Spiess, J. Rivier, W. Vale (1982). In vivo corticotropin-releasing factor-induced secretion of adrenocorticotropin, $\beta$-endorphin and corticosterone. Endocrinology 110, 272-278.

Rolls, B., R. J. Wood (1977). Role of angiotensin in thirst. Pharm. Biochem. Behav. 6, 245-250.

Rossier, J., T. M. Vargo, S. Minick, N. Ling, F. E. Bloom, R. Guillemin (1977). Regional dissociation of $\beta$-endorphin and enkephalin contents in rat brain and pituitary. Proc. Natl. Acad. Sci. USA, 74, 5162-5165.

Saltman, S., A. Baukal, S. Waters, F. M. Bumpris, K. J. Catt (1975). Competitive binding activity of angiotensin II analogues in an adrenal cortex radioligand-receptor assay Endocrinology 97, 275-282.

Schramme, C., C. Denef (1983). Stimulation of prolactin release by angiotensin II in superfused rat anterior pituitary cell aggregates. Neuroendocrinology 36, 483-485.

Schwartz, A., G. E. Lindenmayer, J. C. Allen (1972). The $\mathrm{Na}^{+}, \mathrm{K}^{+}$-ATPase membrane transport system: Importance in cellular function. In : Current Topics in Membranes and Transport, Volume 3, Bronner, F. Kleinzeller, A., editors, pp. 1-81 (Academic Press, New York).

Share, L. (1979). Interrealations between vasopressin and the renin-angiotensin system. Fed.
Proc. 38, 2267-2271.

Sirett, N. E., S. N. Thornton, J. L. Hubbard (1979). Angiotensin binding and pressor activity in the rat ventricular system and midbrain. Brain Res. 166, 139-148.

Sobel, D., A. Vagnucci (1982). Angiotensin II mediated ACTH release in rat pituitary cell culture. Life Sci. 30, 1281-1286.

Steele, M. K., A. Negro-Villar, S. M. McCann (1981). Effect of angiotensin II on in vivo and in vitro release of anterior pituitary hormone in the female rat. Endocrinology 109, 893899.

Summy-Long, J. Y., W. B. Severs (1974). Angiotensin and thirst: studies with a converting enzyme inhibitor and a receptor antagonist. Life Sci., 15, 569-582.

Vale, W., C. Rivier, L. Yang, S. Minick, R. Guillemin (1978). Effects of purified hypothalamic corticotropin-releasing factor and other substances on the secretion of adrenocorticotropin and $\beta$-endorphin-like immunoreactivities in vitro. Endo-crinology 103, 1910-1915.

Vizi, E. S. (1978). $\mathrm{Na}^{+}-\mathrm{K}^{+}$-activated adenosinetriphosphatase as a trigger in transmitter release. Neoroscience, 3, 367-384.

Wakabayashi, K., I. A. Kamberi, S. M. McCann (1969). In vitro response of the rat pituitary to gonado-tropin-releasing factors and to ions. Endocrinology 85, 1046-1056.

Wardlaw, S. L., A. G. Frantz (1979). Measurement of $\beta$-endorphin in human plasma. $J$. Clin. Endocrinol. Metab. 48, 176-180.

Weakly, J. N. (1973). The action of cobalt ions on neuromuscular transmission in the frog. $J$. Phy'siol. 234, 597-612.

Yeo, T., M. O. Thorner, A. Jones, P. J. Lowry, G. M. Besser (1979). The effects of dopamine, bromocriptine, lerbotrile, and met-clopramide on prolactin release from continuously perfused columns of isolated rat pituitary cells. Clin. Endocrinol. 10, 123-130. 